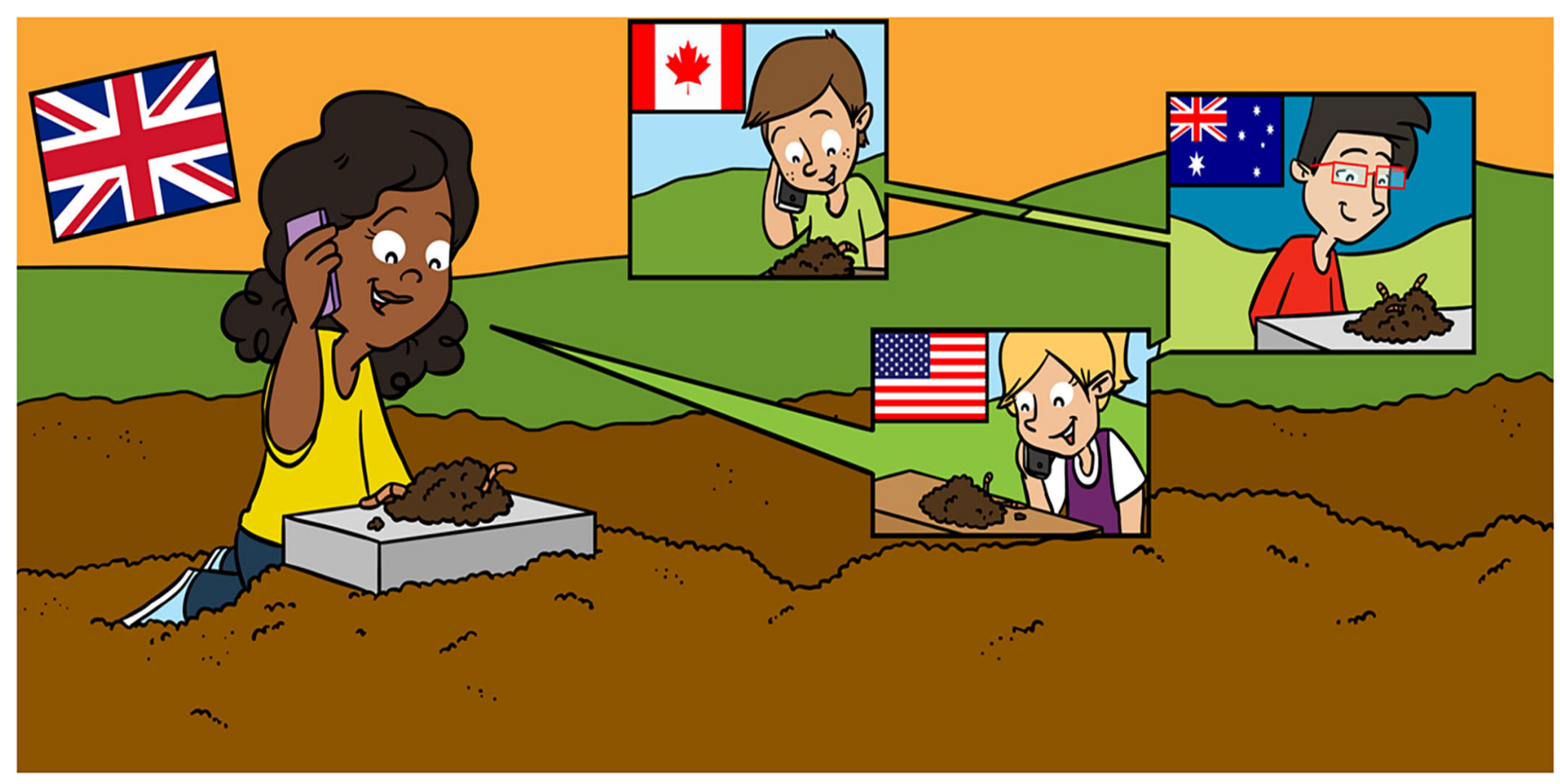

\title{
LEARNING MORE ABOUT EARTHWORMS WITH CITIZEN SCIENCE
}

\section{Victoria J. Burton ${ }^{1 *}$ and Erin K. Cameron ${ }^{2}$}

${ }^{1}$ Life Sciences Department, Natural History Museum, London, United Kingdom

${ }^{2}$ Department of Environmental Science, Saint Mary's University, Halifax, NS, Canada

YOUNG REVIEWER:

AYA

AGE: 9
Have you ever wanted to conduct scientific research? Citizen, or community science involves non-scientists in assisting scientists with research. The term covers a huge variety of projects: from online-only where you can classify galaxies, to practical outdoor activities, and even helping with scientific expeditions. Ideally, citizen science benefits everyone-scientists collect more data, and over larger geographic areas than they could on their own. Non-scientists benefit by learning something new and experiencing how science works, and hopefully having fun! The small size of most soil organisms is challenging for citizen science. However, earthworms are easy to recognize and relatively large, so there have been several citizen science projects focused on them. In this article, we discuss earthworm citizen science from its origins with 18th and 19th century natural historians, to the modern day. Discover what non-scientists have contributed to earthworm science and how you can design your own earthworm investigations. 


\section{CITIZEN SCIENCE}

Scientific studies carried out in whole or part by volunteers rather than paid scientists, also known as community science.

1 setiathome.berkeley. edu/

2 foldingathome.org/

3 www.zooniverse.org/

4 www.birdcount.org

5 freshwaterwatch. thewaterhub.org/

\section{WHY CITIZEN SCIENCE?}

Science is not only carried out by scientists. When other people, like students or families, collect scientific data and help with research, it is called citizen science. Citizen science, also known as community science, allows anyone to participate in research, and its popularity has been increasing. Scientists benefit because this helps them to gather data that would have been difficult, expensive, or impossible for them to collect on their own. On the other hand, citizen scientists gain the opportunity to be directly involved in research and learn about science.

\section{TYPES OF CITIZEN SCIENCE}

There are many kinds of citizen science. Some projects borrow the power of personal computers to search for alien life ${ }^{1}$ or to find cures for diseases ${ }^{2}$. Some online citizen science projects ask people for help with identifying wildlife or galaxies, translating documents, and many more tasks ${ }^{3}$. Other citizen science projects need people to go outside to survey wildlife ${ }^{4}$ or to measure water pollution ${ }^{5}$. There are even expedition-style projects, in which volunteers help scientists with research on volcanoes and rainforests.

\section{WHY STUDY EARTHWORMS?}

Healthy soils are important for all life on Earth, as they recycle nutrients, filter water, and help plants to grow. As earthworms feed and burrow, they mix the soil and provide the nutrients that most plants need. Depending on the location of a study, the scientific questions addressed by earthworm research differ. In some places, like the United Kingdom, earthworms are considered beneficial and scientists want to find out more about where they are, to improve soil health. But in other areas of the world, like most of Canada and the northern United States, the last ice age wiped out the earthworms. Now the only earthworms living there are those that were brought into the region by people, often accidentally, with soil or plants that were imported from Europe. Scientific research in these areas often tries to determine where earthworms are found and how they are spreading, to try to reduce their impacts in forests. Even where earthworms are invasive, they are still usually considered beneficial in gardens and for composting and are only a problem when they escape into wild areas.

\section{CITIZEN SCIENCE FOR EARTHWORMS}

Earthworms were some of the first soil animals to be studied by early scientists and they continue to be studied by scientists today, with 
Figure 1

There are three main types of earthworms, called ecotypes: endogeic, anecic, and epigeic. Some of their characteristics are described here (Credits: earthworm clipart from Vecteezy.com Earthworm photographs (?) Trustees of the Natural History Museum/Harry Taylor).

\section{ECOTYPE}

Groups of earthworms based on their burrowing and feeding habits.

\section{ENDOGEIC}

An earthworm that creates horizontal burrows in soil, feeding on soil as it burrows. Usually pale in color.

\section{ANECIC}

A type of earthworm that builds deep vertical burrows and comes to the surface to feed on leaf litter. Often large and red in color.

\section{EPIGEIC}

Earthworms that feed and burrow on or near the soil surface, feeding on leaf litter. Usually small and red in color.

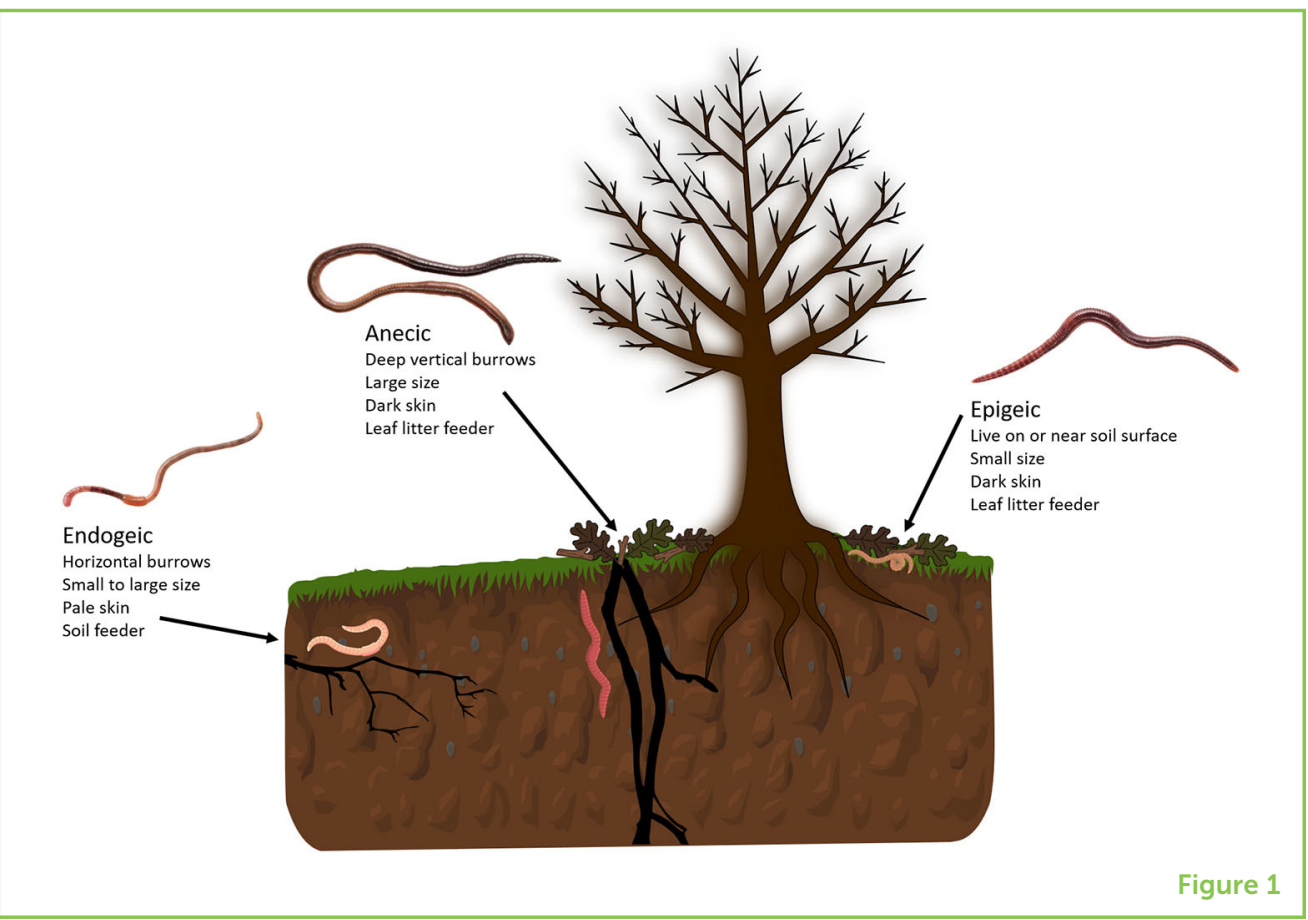

the help of farmers, gardeners, students, and many others. Most soil organisms are small and require special equipment and knowledge to study them, which makes it difficult to include them in citizen science. Earthworms are a happy exception, as they are relatively large and easy to find and observe without special equipment. The usual method for finding earthworms is to dig out a cube of soil from the ground and then search through it by hand, picking out any earthworms. Another method uses a mixture of hot mustard powder and water poured on the soil. If the mustard water touches any earthworms in the soil, they move to the surface where they can be captured, but the mustard does not do permanent harm.

Although the species of most earthworms cannot be identified without a microscope, they can be grouped into different categories according to their lifestyle. These categories are called ecotypes. The three ecotypes-endogeic, anecic, and epigeic (Figure 1)-can usually be distinguished by citizen scientists.

\section{EARLY EARTHWORM CITIZEN SCIENCE}

The earliest natural scientists, such as John Ray (1627-1705) and Carolus Linneaus (1707-1778), grouped all long, wiggly animals together as "worms" and many still have common names that reflect this. Some moth caterpillars are called inchworms, legless lizards are called slow worms, and glowing beetle larvae are known as glow worms. John Ray was the first to record the phrase "the early bird catches the worm" in his book "A Handbook of Proverbs," published in 1670. Linneaus developed rules for naming organisms and named 
the common earthworm Lumbricus terrestris-the same name it has today.

The English pastor Gilbert White (1720-1793) was the first to observe and write about how earthworms live. He described that earthworms seem to promote plant growth and are an important part of the food chain. Inspired by White's writing, Charles Darwin (1809-1882) was also fascinated by earthworms. Darwin's book The Formation of Vegetable Mould Through the Action of Worms, with Observations on their Habits [1] is the result of his 40-years study of earthworms and it was the final book he published, in October 1881. It was very popular, selling 6,000 copies in the first year.

\section{WHAT DID DARWIN DISCOVER ABOUT EARTHWORMS?}

Darwin found that earthworms have no sense of hearing. He discovered this by shouting at earthworms and playing them various musical instruments including a piano, a bassoon, and a tin whistle. However, earthworms in pots placed on a piano hid in their burrows when notes were played, showing that they can sense vibrations through the soil. Darwin also investigated earthworms' sense of smell by blowing tobacco smoke and perfume at them, and they did not react. They can smell their favorite foods though-Darwin experimented with giving captive earthworms many different foods and noted which they preferred. He found that wild cherry leaves were preferred over lime and hazel leaves. Cabbages, horseradish, carrot, and celery were also liked, but herbs, such as sage, thyme, and mint were barely touched.

Darwin observed the way that large stones and ancient buildings are slowly buried, including making a journey to Stonehenge to examine buried stones there. Darwin placed a large stone on the soil surface of his garden and, over 29 years, recorded how long it took the stone to be buried by earthworms. Using this experiment, Darwin estimated that earthworms move $34,000 \mathrm{~kg}$ of soil (the weight of five and a half African elephants) per hectare (about one and quarter soccer pitches)

\section{BIOTURBATION}

The movement of soil by living animals or plants.

\section{EARTHWORM CITIZEN SCIENCE TODAY}

Despite the long history of research involving earthworms, we still do not know enough about where they are most common and how they are affecting other species. Citizen science is helping scientists answer these questions. There are increasing numbers of programs in different parts of the world that involve earthworm sampling (Figure 2 and Table 1). The data citizen scientists collect is mailed to scientists or sent in through smartphone apps. Some of the programs are designed for use in schools and include suggestions for how they fit with 
Figure 2

Examples of earthworm citizen science projects in various countries. OPVT, L'Observatoire Participatif des Vers de Terre.

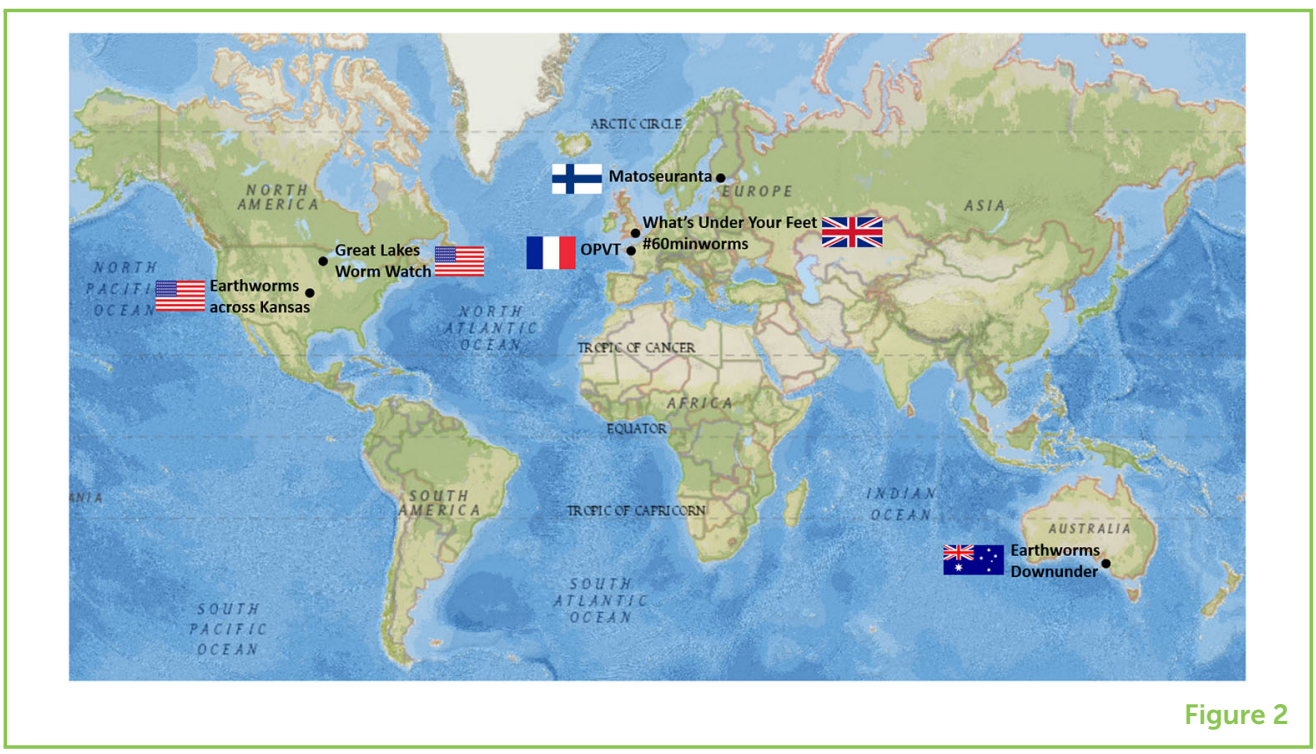

course material, while other programs are designed so that anyone can participate.

\section{DISCOVERIES FROM EARTHWORM CITIZEN SCIENCE}

A lot of the research from citizen science projects is still underway, but there have already been some exciting discoveries. And Citizen Scientists have been extremely important! For example, in the United States, citizen scientists have helped to detect the spread of new species, such as jumping worms (Amynthas species), which were introduced from Asia. In Finland, citizen scientist helped showing that the number of earthworm species decreases moving from the south to the north of the country. In the north, most of the places surveyed had no earthworms or only one species, likely because of the cold temperatures. In the United Kingdom, the OPAL Soil and Earthworm Survey discovered that citizen scientists find it quite difficult to identify earthworm species but can tell ecotypes apart correctly $70-90 \%$ of the time.

The project "What is Under Your Feet?" confirmed that earthworm numbers change with the seasons, with the most found in spring and autumn [3]. There were also more earthworms found after rain. The project \#60minworms counted earthworms from farm fields and found that plowing the soil reduced the number of earthworms [4]. Some farms had no epigeic or anecic earthworms, which may mean the fields are plowed too often. The "Earthworm Watch" project found that gardens that use organic fertilizer, such as manure and compost, have $20 \%$ more earthworms than gardens that added no fertilizers. 


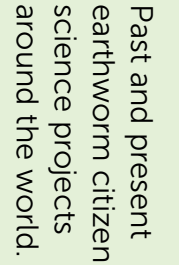

\section{Country}

United States

\section{Canada}

United Kingdom

\section{Project name}

Great Lakes Wormwatch

Earthworms across Kansas

Alberta Worm Invasion

Worm Tracker

\section{WormWatch}

Open Air Laboratory (OPAL)

Soil and Earthworm Survey

What is Under Your Feet?

\section{\#60minworms}

Earthworm Watch

Earthworm Society of

Britain

France

Australia

Finland

Norway
L'Observatoire Participatif des Vers de Terre (OPVT)

Earthworms Downunder

Matoseuranta

Forskningskampanjen 2010-Meitemark

\section{More information}

https://www.k-state.edu/cecd/partnerships/EarthwormsAcrossKansas.htm 2006-today

Anyone

School students

Anyone

Anyone

Anyone

School students

Farmers

Anyone

Anyone

Anyone

School students

School students

School students

https://www k-state edu/earthworm/

2010-2012

https://worms.educ.ualberta.ca/

2013-today

https://www.naturewatch.ca/wormwatch/

2014-today

https://www.imperial.ac.uk/opal-soil

2009-2020

https://jointhepod.org/teachers/other/information-

2018-today pack-whats-under-your-feet

https://www.rothamsted.ac.uk/news/earthworm-research-

spurs-farmers-act

https://earthwormwatch.org/

2016-2018

https://www.earthwormsoc.org.uk/

2009-today

https://ecobiosoil.univ-rennes1.fr/OPVT_accueil.php

2011-today

[2]

1992

http://matoseuranta.it.helsinki.fi/fi

https://www.miljolare.no/aktiviteter/land/natur/ln6/
2016-2018

2010 


\section{HABITATS}

The home environment of animals, plants or other organisms, providing food, shelter, protection and mates.

\section{DOING YOUR OWN EARTHWORM RESEARCH}

Whether earthworms are helpful for harmful for soil health depends where in the world you are, but they are always important. Using citizen science, scientists, students, families, farmers, and anyone else interested, can work together to find out more about earthworms. There are still many unanswered questions about earthworms that you can investigate. Here are a few suggestions if you want to start your own project on earthworms:

- Recreate one of Darwin's experiments-how long do earthworms take to bury a stone in your garden? Does this vary depending on where the stone is in your garden?

- How does season affect the number of earthworms found in your garden, or the number of different types of earthworms?

- How does the number and types of earthworms vary across different habitats (like your garden compared with a forest)?

- Start a compost bin in your yard-how long does it take for earthworms to arrive?

\section{REFERENCES}

1. Darwin, C. 1882. The Formation of Vegetable Mould Through the Action of Worms With Observations on Their Habits. London: John Murray. Available online at: http://darwin-online.org.uk/Editoriallntroductions/Freeman_ VegetableMouldandWorms.html

2. Baker, G. H., Thumlert, T. A., Meisel, L. S., Carter, P. J., and Kilpin, G. P. 1997 "Earthworms downunder": a survey of the earthworm fauna of urban and agricultural soils in Australia. Soil Biol. Biochem. 29:589-97. doi: 10.1016/ S0038-0717(96)00184-8

3. Martay, B., and Pearce-Higgins, J. W. 2018. Using data from schools to model variation in soil invertebrates across the UK: the importance of weather, climate, season and habitat. Pedobiologia 67:1-9. doi: 10.1016/j.pedobi.2018.01.002

4. Stroud, J. L. 2019. Soil health pilot study in England: outcomes from an on-farm earthworm survey. PLOS ONE 14:e0203909. doi: 10.1371/journal.pone.0203909

SUBMITTED: 02 April 2020; ACCEPTED: 07 December 2020;

PUBLISHED ONLINE: 14 January 2021.

EDITED BY: Rémy Beugnon, German Centre for Integrative Biodiversity Research (iDiv), Germany

CITATION: Burton VJ and Cameron EK (2021) Learning More About Earthworms With Citizen Science. Front. Young Minds 8:548525. doi: 10.3389/frym.2020.548525

CONFLICT OF INTEREST: The authors declare that the research was conducted in the absence of any commercial or financial relationships that could be construed as a potential conflict of interest. 


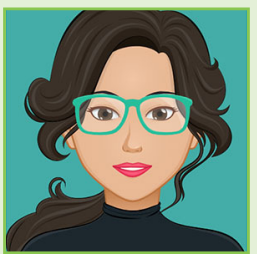

COPYRIGHT @ 2021 Burton and Cameron. This is an open-access article distributed under the terms of the Creative Commons Attribution License (CC BY). The use, distribution or reproduction in other forums is permitted, provided the original author(s) and the copyright owner(s) are credited and that the original publication in this journal is cited, in accordance with accepted academic practice. No use, distribution or reproduction is permitted which does not comply with these terms.

\section{YOUNG REVIEWER}

\section{AYA, AGE: 9}

Aya wants to study marine biology. She wants to specialize in sharks and rays. Her favorite subjects in school are reading, writing, math, and music. In her free time she likes to read books, try out challenging puzzles, training for track and cross country, experimenting with different art techniques, and roller skating.

\section{AUTHORS}

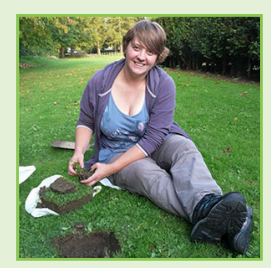

\section{VICTORIA J. BURTON}

I spent my childhood playing outside, making nature journals, and learning how to identify plants, birds, and insects in the woods. I did not like school but always wanted to be a scientist, so I studied for a degree with The Open University. I have just finished my Ph.D. with Imperial College London, where I researched how soil and leaf-litter invertebrate communities respond to human activities. In my free time I enjoy looking after my pets and plants and helping run the Bug Club for young people interested in insects. *v.burton@ nhm.ac.uk

\section{ERIN K. CAMERON}

I enjoyed playing outside as a child and loved science but did not consider becoming a biologist until I was in university. Eventually, I started helping with research examining how human activities affect songbirds and found it fascinating. Once I started to work on soil organisms and saw how much is still unknown about them, I was convinced that I wanted to study ecology. Now I investigate how human activities affect soil biodiversity and the functioning of ecosystems. I enjoy cross-country skiing, bicycling, and kayaking in my free time. 